American Journal of Life Sciences
2020; 8(5): $121-126$
http://www.sciencepublishinggroup.com/j/ajls
doi: 10.11648 /j.ajls.20200805.16
ISSN: 2328 -5702 (Print); ISSN: $2328-5737$ (Online)

\title{
Microbial Protein Production from Agro-industrial Wastes as Food and Feed
}

\section{Tirsit Tibebu Bogale}

Microbial Biotechnology Research Program, National Agricultural Biotechnology Research Center, Ethiopian Institute of Agricultural Research, Holeta, Ethiopia

Email address:

mynestjune29@gmail.com

\section{To cite this article:}

Tirsit Tibebu Bogale. Microbial Protein Production from Agro-industrial Wastes as Food and Feed. American Journal of Life Sciences. Vol. 8, No. 5, 2020, pp. 121-126. doi: 10.11648/j.ajls.20200805.16

Received: March 4, 2020; Accepted: March 31, 2020; Published: September 3, 2020

\begin{abstract}
Microbial protein refers to dead, dry microbial cells or total proteins extracted from pure microbial cell culture and is produced using a number of different microorganisms including bacteria, yeasts, filamentous fungi, and algae, which are used as protein supplement in human foods or animal feeds. It can also be called single cell protein, bio protein or biomass. Microorganisms, utilize inexpensive feedstock and wastes as sources of carbon and energy for growth to produce biomass, protein concentrate or amino acids. Besides high protein content (about $60-82 \%$ of dry cell weight), microbial protein also contains fats, carbohydrates, nucleic acids, vitamins and minerals like potassium, phosphorus. Another advantage with microbial protein is that it is rich in certain essential amino acids like lysine, methionine which are limiting in most plant and animal. With increase in population and worldwide protein shortage the use of microbial biomass as food and feed is more highlighted. One of the most prominent applications of microbial protein (single cell protein) is that it can be used as dietary supplements to address important issues like malnutrition especially in the developing countries.
\end{abstract}

Keywords: Microbial Biomass, Microbial Protein, Microorganisms

\section{Introduction}

The increasing world deficiency of protein is becoming a main problem of humankind. Since the early fifties, intense efforts have been made to explore new, alternate and unconventional protein. For this reason, in 1996, new sources mainly yeast, fungi, bacteria and algae named Single Cell Protein (SCP) as coined to describe the protein production from biomass, originating from different microbial sources. Microbial biomass has been considered an alternative to conventional sources of food or feed.

Yeast was the first microorganism whose importance as animal feed supplement was recognized almost a century ago. During World War I, Germany replaced half of imported protein sources by yeast. Pruteen was the first commercial single cell protein used as animal feed additive. From a nutritional viewpoint, Nucleic Acids (NA) content in SCP is one of the main factors hindering its utilization as food. Excessive intakes of NA lead to uric acid precipitation, causing health disorders, such as gout or kidney stone formation [13].
So, in human their NA contents must be reduced below $2 \%$. Several technologies have been reported to reduce the NA content of microbial cells, including both chemical and enzymatic procedures. Chemical and enzymatic methods have disadvantages [23]. Various microorganisms used for the production of SCP are bacteria (Cellulomonas, Alcaligenes, etc.), algae (Spirulina, Chlorella, etc.), molds (Trichoderma, Fusarium, Rhizopus, etc.) and yeast (Candida, Saccharomyces, etc.). Microorganisms can utilize a variety of substrate like agricultural wastes and effluents, industrial wastes, natural gas like methane, etc. that also help in decomposing pollutants [15].

Yeasts have advantages such as their larger size (easier to harvest), lower nucleic add content, high lysine content and ability to grow at acidic $\mathrm{pH}$. However, the most important advantage is familiarity and acceptability because of the long history of its use in traditional fermentations. Disadvantages include lower growth rates, lower protein content (45 to $65 \%$ ) and lower methionine content than in bacteria. Filamentous fungi have advantages in ease of harvesting, but have their limitations in lower growth rates, lower protein 
content and acceptability [28].

Algae have disadvantages of having cellulosic cell walls which are not digested by human beings. Secondly, they also concentrate heavy metals. In the case of algae it has to be stressed that, due to technical and economical reasons, it is not the general intention to isolate and utilize the sole protein, but to propagate the whole algal biomass. So, the term SCP is not quite correct, because the micro-algal material is definitely more than just protein. To date, worldwide various sophisticated technologies are employed for mass production and processing of photoautotrophic microalgae [13].

Single cell proteins have application in animal nutrition as: fattening calves, poultry, pigs and fish breading in the foodstuffs area as: aroma carriers, vitamin carrier, emulsifying aids and to improve the nutritive value of baked products, in soups, in ready-to-serve meals, in diet recipes and in the technical field as: paper processing, leather processing and as foam stabilizers [20]. The production of single cell protein takes place in a fermentation process. This is done by selected strains of microorganisms which are multiplied on suitable raw materials in technical cultivation process directed to the growth of the culture and the cell mass followed by separation processes.

Process development begins with microbial screening, in which suitable production strains are obtained from samples of soil, water, air or from swabs of inorganic or biological materials and are subsequently optimized by selection, mutation, or other genetic methods. Then the technical conditions of cultivation for the optimized strains are done and all metabolic pathways and cell structures will be determined [21]. Besides, process engineering and apparatus technology adapt the technical performance of the process in order to make the production ready for use on the large technical scale. Here is where the economic factors (energy, cost) come into play.

Safety demands and environmental protection is also considered in the production of SCP in relation both to the process and to the product. Finally, safety and the protection of innovation throw up legal and controlled aspects, namely operating licenses, product authorizations for particular applications and the legal protection of new process and strains of microorganisms [30].

\section{Choice of Microorganism for SCP Production}

\subsection{Bacteria}

Among bacterial species, Cellulomas and Alcaligenes are the most frequently used bacterial species as a single cell proteins source [9]. Potential phototrophic bacterial strains are recommended for single cell protein production. Some researchers also suggest use of methanotrophic and other bacterial species for single cell protein production. Generation time of Methylophilus methylotrophus is about 2 hours and this bacterium is used in animal feed; in general produce a more favorable protein composition than yeast or fungi. Therefore the large quantities of single cell protein animal feed can be produced using bacteria [9].

Characteristics that make bacteria suitable for this application include rapid growth of bacteria, short generation times of bacteria - almost can double their cell mass in 20 minutes to 2 hours [6]. They are also capable of growing on a variety of raw materials that range from carbohydrates such as starch and sugars to gaseous and liquid hydrocarbons which include methane and petroleum fractions; to petrochemicals such as methanol and ethanol; nitrogen sources which are useful for bacterial growth include ammonia, ammonium salts, urea, nitrates, and the organic nitrogen in wastes, also it is suggested to add mineral nutrient supplement to the bacterial culture medium to fulfill deficiency of nutrients that may be absent in natural waters in concentrations sufficient to support growth [6]. The use of bacteria is somewhat limited by poor public acceptance of bacteria as food, small size and difficulty of harvesting and high content of nucleic acid on dried weight basis [20].

\subsection{Yeasts and Fungi}

Many fungal species are used as sources of protein rich food. Among these, most popular are yeast species, Candida, Hansenula, Pitchia, Torulopsis and Saccharomyces. Many other filamentous species are also used as sources of single cell protein. Actinomycetes and filamentous fungi were reported to produce protein from various substrates. Cultures of Fusarium and Rhizopus have been grown in fermentation as a source of protein food [20]. The inoculum of Aspergillus oryzae or Rhizopus arrhizus is selected because of their non-toxic nature. Saprophytic fungi grow on complex organic compounds and convert them into simple structures. High amount of fungal biomass is produced as a result of growth. Mycelial yield vary greatly which depends upon organisms and substrates. There are some species of moulds, for example, Aspergillus niger, Aspergillus fumigatus, Fusarium graminearum which are very dangerous to human, therefore, such fungi must not be used or toxicological evaluations should be done before recommending to use as Single cell protein [37]. Yeasts are probably the most widely accepted and used microorganism for single cell protein

\subsection{Algae}

Since ancient times, Spirulina was cultivated by people near Lake Chad in Africa and the Aztecs near Lake Texcoco in Mexico. They used it as food after drying it. Spirulina is the most widely used algae. Similarly, biomass obtained from Chlorella and Senedessmus is harvested and used as source of food by tribal communities in certain parts of the world. Algae are used as a food in many different ways and its advantages include simple cultivation, faster growth and rich in protein content [3]. The production of algae could be limited by certain conditions such as the need for warm temperatures and plenty of sunlight in addition to carbon 
dioxide [20]. Another disadvantage associated with using algae as single cell protein is that digestibility is low with algal cells because of indigestible cell walls [36].

\section{Potential Substrates for SCP Production}

\subsection{Molasses}

The residual liquid obtained after crystallization of sugar from the concentrated sugar solution obtained from the milling of sugar cane or sugar beet, contains $4555 \%$ sugars, namely sucrose, glucose, fructose, raffinose, melibiose and galactose. It is estimated that for every $100 \mathrm{~kg}$ of cane milled for sugar production, some 3.5 to $4.5 \mathrm{~kg}$ of molasses is obtained. The use of molasses for the production of SCP is determined by its availability and low cost, its composition and absence of toxic substances and fermentation inhibitors [7]. Though molasses is a suitable carbon feedstock for SCP production, it requires supplementation with ammonia salts and phosphorus salts [33]. Cassava is a tropical root crop produced in more than 80 countries and it is a rich source of starch for SCP production.

\subsection{Dairy Waste}

Whey can be categorized as monosaccharides and disaccharides rich source or protein or lipid rich source. If dairy waste is high in lactose, these by-products can be used as suitable substrate for SCP production using microorganisms capable of fermenting lactose [25].

\subsection{Fruit Waste (Simple Sugar Rich)}

The content of fruit processing waste is highly dependent on the type of fruit and the part of the fruit that forms the main mass of the waste. If the waste is mainly whole fruit, then a large amount of monosaccharides and disaccharides will be available in the waste, as it is in the case with banana wastes, where 5 to $30 \%$ of harvested bananas are discarded as waste

\subsection{Starch Rich Sources}

Starch rich waste products, such as grains and tuber residues, account for a large proportion of agricultural waste. Starch rich substrates need to be hydrolysed to monosaccharides prior to use them in cultivation, which may increase the cost of production of SCP.

\subsection{Bran}

Bran is a by-product of grain processing, which is commonly used in oil extraction, animal feed or as a food additive. In general, all types of grain bran have a high content of starch, fibre and protein and bran is also a good source for lipids, iron, vitamin B, phenolic acid, phytosterol and antioxidants [34].

\section{Single Cell Protein can Be Produced by Fermentation Processes}

\author{
Cultivation methods \\ i. i. Submerged fermentation \\ ii. ii. Semisolid fermentation and \\ iii. iii. Solid state fermentation
}

\subsection{Submerged Fermentation}

In submerged process, the substrate used for fermentation is always in liquid state which contains the nutrients needed for growth [35]. Submerged culture fermentations require more capital investment and have high operating cost. The fermenter containing the substrate is operated continuously and the product biomass is continuously harvested from the fermenter by using different techniques. The product is filtered or centrifuged and then dried. High oxygen transfer rate promotes high respiration rate this brings about increase metabolic heat generation during cultivation [29]. This is removed by using a cooling device. The microbial biomass can be harvested by various methods [16]. Single cell organisms like yeast and bacteria are recovered by centrifugation while filamentous fungi are recovered by filtration. It is important to recover as much water as possible prior to final drying which is done under clean and hygienic conditions.

Liquid state fermentation is performed in tanks, which can reach 1,001 to 2,500 square metres $(10,770$ to $26,910 \mathrm{sq} \mathrm{ft})$ at an industrial scale. Liquid culture is ideal for the growing of unicellular organisms such as bacteria or yeasts. To achieve liquid aerobic fermentation, it is necessary to constantly supply the microorganism with oxygen, which is generally done via stirring the fermentation media. Accurately managing the synthesis of the desired metabolites requires regulating temperature, soluble oxygen, ionic strength and $\mathrm{pH}$ and control nutrients [10].

\subsection{Semisolid Fermentation}

In semisolid fermentation, the substrate is usually used in solid state e.g. cassava waste [1]. The cultivation involves many operations which include stirring and mixing of a multiphase system; transport of oxygen from the gas bubbles through the liquid phase to the microorganisms; and the process of heat transfers from liquid phase to the surroundings [2]. A special bioreactor is designed for identifying mass and energy transportation phenomena, called U-loop fermenter [22]. Production of single cell protein involves basic steps of preparation of suitable medium with suitable carbon source, prevention of the contamination of medium and the fermenter, production of microorganisms with desired properties and separation of synthesized biomass and its processing [27]. Carbon source used can be n-alkenes, gaseous hydrocarbons, methanol and ethanol, renewable sources like carbon oxide molasses, polysaccharides, effluents of breweries and other solid substances [32]. 


\subsection{Solid State Fermentation}

Solid state fermentation (SSF) has been extensively studied with thousands of publications describing various types of bioreactor designs, process conditions and microorganisms for the production of various value added products like single cell protein, feeds, enzymes, ethanol, organic acids, B- complex vitamins, pigments, flavors [26]. This process consists of depositing a solid culture substrate, such as rice or wheat bran, on flatbeds after seeding it with microorganisms; the substrate is then left in a temperature controlled room for several days.

\section{Acceptability and Toxicology of SCP}

The name of the raw materials used in SCP processes represents the main safety hazard. Toxicology testing of the final product must include short-term acute toxicity testing with several different laboratory animal species, followed by extensive and detailed long term studies. It represents a major scientific and financial investment. The acceptability of SCP when presented as a human food does not depend only on its safety and nutritional value. In addition to the general reluctance of people to consume material derived from microbes, the eating of food has many subtle psychological, sociological and religious implications [21].

\section{SCP Processing for Food}

The effective use of microbial protein for human food requires:

1. Liberation of cell proteins by destruction of indigestible cell walls.

2. Reduction of nucleic acid content.

\subsection{Methods of Cell Wall Destruction}

The use of microorganism for refined SCP requires not only an adequate amount of specific organism but also an efficient means of disrupting the cell wall [5]. Mechanical integration of cell wall can be carried out either by crushing, crumbling, grinding, pressure homogenization or ultra sonification. Various enzymes or combination of enzymes can be used to digest and disrupt cell wall, either partially or completely. Enzymatic hydrolysis of cell wall is attractive in terms of its delicacy and specificity for only the cell wall structure. It may be used as an alternative to the mechanical disruption, especially for materials that can be inactivated during the mechanical process and it can be performed by endogenous or exogenous enzyme from other microorganisms. However, extensive enzymatic lysis of cells is a very slow process compared to mechanical disruptions. It is possible to use two or more methods for cell disruptions. Combined mechanical and enzymatic degradation of yeast cell wall was tested [4].

In case of yeast cells they first can be mechanically broken and then incubated with a lytic enzyme [11]. This resulted in the release of a substantial amount of protein mostly from organelles and cell walls. [5] reported enhanced disruption of Candida utilis by enzymatic pretreatment and high-pressure homogenization. Other methods employed for yeast cell breakage include: autolysis followed by enzymatic or alkali treatments [8], $\mathrm{NaCl}$ induced autolysis at different temperature, chemical disintegration using detergent such as sodium dodecyl sulfate or Triton X-100, acid or solvent [18]. The digestibility of yeast and microalgae can be greatly increased by drying at high temperature under certain conditions. However, the heat treatment needed to increase the digestibility of the cells also affects the protein quality and other valuable cell components [14].

Here are the methods for cell disruption:

Non-mechanical methods

1. Chemical treatment: acid, base, solvent, detergent

2. Enzyme analysis: lytic enzymes, phage infection, autolysis

3. Physical treatment: freeze-thaw, osmotic shock, heating and drying

Mechanical methods

1. High pressure homogenization

2. Wet milling

3. Sonification

4. Pressure extrusion: french press, freeze pressing

5. Decompression (pressure chamber)

6. Treatment with grinding particles [12]; [19].

\subsection{Removal of Nucleic Acids}

Several methods have been proposed to reduce nucleic acid levels in SCP. These methods involve chemical and enzymatic treatments. Each has disadvantages both in terms of cost and potential nutritional concern. In 1977, the extraction of nucleic acid by acidified alcohol, salt, acid and alkalis has been proposed. The process resulted in high protein yield with low nucleic acid. However, alkaline hydrolysis of nucleic acid at high temperature causes the formation of potentially toxic compounds such as lysinoalanine. It is an unusual amino acid involved in crosslinking of alkaline protein. Lysinoalanine has been shown to reduce digestion and induce kidneys changes in rats [11].

It also implicated in skin allergy in some persons consuming treated protein [24]. Chemical modification of yeast nucleoproteins with anhydrides has been used to reduce the nucleic acid levels. Yeast contains considerable amounts of endogenous ribonulease activity that is used to hydrolyzed yeast RNA and that cause reduction of nucleic acid level in yeast protein. At the optimum conditions of ribonuclease activity, significant activation of endogenous protease also occurs. This result in proteolytic degradation of protein and thereby, decreases the yield of protein. Alternatively, nuclease has been added exogenously to reduce the nucleic acid content of SCP.

Pancreatic ribonuclease (RNase A) and a fungal ribonuclease of Aspergillus candidus strain M16 has been used as the source of exogenous nuclease for the reduction of nucleic acid in the cells of yeast species allowing a substantial reduction of NA [17]. Bacterial or pancreatic nucleases have been also studied for NA removal from yeast 
cells. Hydrolysis of NA has also been performed by using immobilized enzymes [23].

\section{Conclusion}

Single celled protein (SCP) production, referring to the fact that most of the micro-organisms used as producers grow as single or filamentous individuals rather than as complex multi-cellular organism such as plants or animals. Use of microbes in the production of proteins gives many advantages over the conventional method methods. Microbes have shorter generation time, allow easy transformation, utilize many substrates, have no requirements in arable land or any particular season to grow and have the possibility of continuous production in any part of the world. The cell yield varies according to the substrate and type of microorganism.

\section{References}

[1] Adedayo MR, Ajiboye EA, Akintunde JK, Odaibo A (2011) Single cell proteins: as nutritional enhancer. Adv Appl Sci Res 2: 396-409.

[2] Andersen BR, Jorgensen JB, Jorgensen SB (2005) U-loop reactor modelling for optimization. Part 1: estimation of heat loss. J Environ Issues 9: 88-90.

[3] Arora DK, Mukerji KG, Marth EH (1991) Single cell protein from molds and higher fungi. In: Hand book of applied mycology: foods and feeds, vol. 3, Banaras Hindu University, Varanasi, India, pp. 499-539.

[4] Asenjo, J. A. and P. Dunnill (1981). The isolation of lytic enzymes from Cytophaga sp. and their application to the rupture of yeast cells. Biotechnol. Bioeng., 23: 1045-1056.

[5] Baldwin, C. V. and C. W. Robinson (1994). Enhanced disruption of Candida utilis using enzimatic pretreatment and high pressure homogenization. Biotechnol. Bioeng., 43: 4656.

[6] Bamberg JH. (2000). British petroleum and global oil 19501975: the challenge of nationalism. Cambridge University Press, Cambridge 6: 445-478.

[7] Bekatorou A., Psarianos C., Koutinas A. A. (2006). Production of food grade yeasts. Biopolymers 44, 407-415.

[8] Benaiges, M. D., J. Lopez-Santin and C. Sola (1989). Partial purification of 5-phosphodiesterase activity from barley rootlets. Enzyme Microbiol. Technol., 11: 444-451.

[9] Bhalla TC, Sharma NN, Sharma M, Gunasekaran P (2007). Production of metabolites, industrial enzymes, amino acids, organic acids, antibiotics, vitamins and single cell proteins. National Science Digital Library, India.

[10] Capalbo DM, Valicente FH, Moraes IO, Pelizer LH (2001). Solid-state fermentation of Bacillus thuringiensis tolworthi to control fall armyworm in maize. Electron J Biotechnol 4: 1-4.

[11] Damodaran, S. and J. E. Kinsella (1983). The use of chaotropic salts for separation of ribonucleic acids and proteins from yeast nucleo-proteins. Biotechnol. Bioeng., 25: 761-770.
[12] Engler, C. R. (1985). Disruption of Microbial Cells. In: Comprehensive Biotechnology, Moo-Young, M. and C. L. Cooney (Eds.). Pegamon Press, Oxford, UK., pp: 305-324.

[13] Hamdy, H. S. (2013). Production of mini-food by Aspergillus niger, Rhizopus oryzae and Saccharomyces cerevisiae using orange peels. Romanian Biotechnological Letters. 18 (1): 7929-7946.

[14] Hedenskog, G and H Morgen, (1973) Some methods for processing of single cell protein Biotechnol Bioeng., 15: 129142.

[15] Huang, Y. T and J. E Kinsella, 1986 Functional properties of phosphorylated yeast protein: Solubility, water-holding capacity and viscosity J Agric Food Chem., 344: 670-674.

[16] Kargi F, Shuler ML, Vashon R, Seeley Jr HW, Henry A, et al (1980) Continuous aerobic conversion of poultry waste into single-cell protein using a single reactor: kinetic analysis and determination of optimal conditions Biotechnol Bioeng 22: 1567-1600.

[17] Kunhi, A. A. M and M. R. R Rao (1995) The utility of a fungal ribonuclease for reducing the nucleic acid content of permeabilized yeast cells Food Biotechnol., 9: 13-28.

[18] Lee, B. H (1996) Fundamentals of Food Biotechnolory Wiley$\mathrm{VCH}$, New York.

[19] Middelberg, A. P. J., 1995 Process-scale disruption of microorganisms Biotechnol Adv., 13: 491-551.

[20] Mondal AK, Sengupta S, Bhowal J, Bhattacharya DK (2012) Utilization of fruit wastes in producing single cell protein Int J Sci Environ Technol 1: 430-438.

[21] Nasseri, A. T., S Rasoul-Amini, M. H Morowvat and Y Ghassemi (2011) Single Cell Protein: Production and Process American Journal of Food Technology 6 (2): 103-116.

[22] Oscar AP, Jorgensen JB, Jorgensen SB (2010) Systematic model analysis for single cell protein (SCP) production in a Uloop reactor 20th European Symposium on Computer Aided Process Engineering - ESCAPE 20.

[23] Parajo, J. C., V Santos, H Dominguez and M Vazquez (1995) $\mathrm{NH}_{4} \mathrm{OH}$-based pretreatment for improving the nutritional quality of single cell protein Applied Biochem Biotechnol., 55: 133-149.

[24] Scrimshaw, N. S and J. C Dillen (1977) Single Cell Protein as Food and Feed In: Single Cell Protein-safety for Animal and Human Feeding, Garattini, S., S Paglialunga and N. S Scrimshaw (Eds.) Pergamon Press, Oxford, UK., pp: 171-173.

[25] Singh, J. K, R. L Meshram and D. S Ramteke (2011) Production of Single cell protein and removal of 'C OD' from dairy waste water European Journal of Experimental Biology, 1 (3): 209-215.

[26] Singhania RR, Patel AK, Soccol CR, Pandey A (2009) Recent advances in solid-state fermentation Biochem Eng J 44: 13-18.

[27] Soland L (2005) Characterization of liquid mixing and dispersion in a U-loop fermentor Am Eur J Agric Environ Sci 67: 99-109.

[28] Srividya, A. R., V. J Vishnuvarthan, M Murugappan and P. K Dahake (2013) Single Cell Protein: Review International Journal of Pharmaceuticals Scholars 2 (4): 14p. 
[29] Srividya AR, Vishnuvarthan VJ, Murugappan M, Dahake PG (2014) Single cell protein- a review Int J Pharm Res Scholars 2: 472-485.

[30] Steinkraus, K. H (1986) Microbial Biomass Protein Grown on Edible Substrates: The Indigenous Fermented Foods In: Microbial Biomass Protein, Moo-Young, M and K. F Gregory (Eds.) Elsevier Applied Science, London, pp: 35-45.

[31] Suman G, Nupur M, Anuradha S, Pradeep B (2015) Single cell protein production: a review Int J Curr Microbiol Appl Sci 4: $251-262$.

[32] Talebnia F (2008) Ethanol production from cellulosic biomass by encapsulated Saccharomyces cerevisiae $\mathrm{PhD}$ Thesis, Chalmers University of technology, Gotheburg, Sweden 334: 113-145.

[33] Ugalde, U. O \& Castrillo, JI (2002) Applied mycology and biotechnology Agriculture and food production 2, 123149.
[34] Valentino, M. J. G., Ganado, L. S \& Undan, J. R (2016) Single cell protein potential of endophytic fungi associated with bamboo using rice bran as substrate Adv in Appl Sci Res 7 (3), 6872 Valmaseda.

[35] Varavinit S, Srithongkum P, De-Eknamkul C, Assavanig A, Charoensiri K (1996) Production of single cell protein from cassava starch in air-lift fermenter by Cephalosporium eichhorniae Starke 48: 379-382.

[36] Ware SA (1977) Single cell protein and other food recovery technologies from wastes Municipal environmental research laboratory office of research and development, U.S environmental protection agency, Cincinnati, Ohio 45268, USA.

[37] Weitzel W, Winchel M (1932) The yeast its nutritive and therapeutic value Verlag Rothgiese und Diesing, Berlin, Germany. 